\title{
Basic Ideas of State Power Limitation in Political and Legal Doctrine
}

\author{
Galina S. Belyaeva ${ }^{1}$, Boris V. Makogon ${ }^{1}$, Sergej N. Bezugly ${ }^{1}$, Marina L. Prokhorova ${ }^{2} \&$ Dariusz Szpoper $^{3}$ \\ ${ }^{1}$ Belgorod State University, 85 Pobedy St., Belgorod, Russia \\ ${ }^{2}$ Kuban state University, 149 Stavropol'skaya St., Krasnodar, Russia \\ ${ }^{3}$ University of Warmia and Mazury in Olsztyn, 2 Michała Oczapowskiego St., Olsztyn, Poland \\ Correspondence: Galina S. Belyaeva, Belgorod State University, 85 Pobedy St., Belgorod, 308015 Russia. \\ E-mail: russia@prescopus.com
}

Received: June 19, 2017

doi:10.5539/jpl.v10n4p197
Accepted: July 18, $2017 \quad$ Online Published: August 30, 2017

URL: https://doi.org/10.5539/jpl.v10n4p197

\begin{abstract}
The article deals with some issues of the state power restriction, and the necessity of this is justified. The evolution of state power restriction certain criteria and forms are analyzed in accordance with the emergence of relevant ideas and scientific concepts and their chronology: the restriction of power by another power, self-restraint of state power; the restriction of state power by the law and human rights in connection with the contemporary problems of state power restrictions in a state governed by the rule of law.
\end{abstract}

Keywords: state power, limitation, self-restraint, law, human rights, rule-of-law state

\section{Introduction}

Legal regulation of state power provides for its ordering: on the one hand, it is the organizational and meaningful strengthening of the power institutions, the provision of competence for them, and on the other hand, the restriction of power by a certain system of rules. At that it should be borne in mind, that the restriction of state power is initially ambivalent and even contradictory one: on the one hand, it is an absolute blessing, since it ensures the implementation and the protection of human rights and freedoms, on the other hand, a state must be strong to ensure the protection of civil rights by the potential use of state coercive means. Many scholars paid attention to this duality of state power. In particular, the German jurist R. Iering noticed that the weakness of power is a mortal sin of the state, which is less forgiven to leaders than the cruelty and tyranny (Jhering, 1915).

Indeed, state power objectively and indisputably needs limitations, otherwise it risks to become a spontaneous uncontrolled phenomenon, devoid of its main purpose - serving the interests of an individual and society. Considering the stated above and accepting the restriction of state power as an obligatory condition for the stability of a state, it seems necessary to analyze the main criteria and the forms of its restriction.

It is noteworthy that the problem of finding the criteria of state activity limitation was in the ancient times. Thus, the writings by Aristotle, Plato, Panetia, Polybius, Lucretia, Cicero, their teachings on the three main state forms (monarchy, aristocracy, democracy), about the development of this evolutionary chain and the deviations from the "correct" forms (tyranny, oligarchy, ochlocracy) one can find the beginnings of ideas about the phenomena acting as such (Marias, 2012).

The theories and the concepts of state power restriction were also developed in the doctrine about the law of war and peace written by G. Grotius (Neff, 2012), the theory of a state by T. Hobbes (Hobbes, 2010), the theory of separation of powers by S. Montesquieu (Montesquieu \& Richter, 1970), the theory of the social contract by J.-J. Rousseau (Wraight, 2008), the doctrine of law by I. Kant (Kant, 2010), the philosophy of law by G.V.F. Hegel (Hegel, 2008), the teachings on the limits of state activity by V. Humboldt (Humboldt, 1969), the "struggle for law" by R. Iering (Jhering, 1915), the social transformation of law and state by L. Dyugi (Duguit, 1917), on the Constitution and the sovereignty of a state by K. Schmitt (Schmitt, 2008), the institutional theory of public law by M. Oriou (Hauriou, 1929), etc.

In the twentieth and early twenty-first centuries, the issue under study was further developed in the works of such foreign scholars as Baumgardt D. (Baumgardt, 1952), Dahl R.A. (Dahl, 1998), Dinwiddy J. (Dinwiddy, 1989), Friedrich C., Brzezinski Z. (Friedrich \& Brzezinski, 1996), Harrison R. (Harrison, 1993), Hart H.L.A. (Hart, 1994), Hayek F A. (Hayek, 1973), Hume L. J. (Hume, 2004), Ishay M. (Ishay, 2008), Lijphart A. (Lijphart, 
1977), Rosen F. (Rosen, 1990), Struan J. (Struan, 1991), Zhang B. (Zhang, 1982), Zuckerman A. (Zuckerman, 1975).

\section{Methodology}

During the process of study, the classical methodology of systems and processes qualitative analysis was used, in particular, the system-analytical approach to the study of research objects.

The methodological foundations of the study include: the system-holistic approach to legal phenomena, which allows to describe them as the systems that have not only internal but also external links; The sociological approach to law, its research in action and evolution (functioning); a comparative legal approach that involves the exchange of information at the level of the world legal science and the search for new parameters of legal reality phenomena comparison from different countries.

\section{Discussion and Results}

There is an unequivocal answer to the issue of criteria limiting state power and there can't be such an answer, since the idea of state power restriction received various incarnations at various periods of historical development.

Chronologically, the idea of a counterweight appears as the first one, according to which state power activity is limited by another power: the divine (T. Aquinas (Lindberg, 1980)), the constitutive (J. Locke (Locke \& Laslett, 1988)), J.-J. Rousseau (Wraight, 2008)), the people (J.-J. Rousseau (Wraight, 2008)) and others.

The second idea in the course of power restriction idea evolution is the idea of state activity (power) self-restraint (J. Locke (Locke \& Laslett, 1988), Sh.L. Montesquieu (Friedrich \& Brzezinski, 1996) et al.), really embodied in the theory of power separation. In the modern understanding, the principle of powers separation between different power branches was first developed in England during the 13-th century. Since then it has passed from the system of power separation with the priority of the one power branch (G. Locke (Locke \& Laslett, 1988)) to the mechanism of power separation on the basis of checks and balances system ensuring their equal interaction and balancing on the basis of law (Sh.L. Montesquieu (Montesquieu \& Richter, 1970)).

In practice, the principle of power separation was recorded originally in the constitutions of Virginia (1776) and Massachusetts (1780), and in 1787 the US Constitution declared three branches of power: legislative, executive and judicial one: "Legislative, executive and judicial bodies should be divided and different, so that none of them can use the power, definitely belonging to another: also no person can exercise a power greater than the power of one body" (United States Constitution. Date Views 25.02.2017).

In 1879, the Declaration of Rights and Liberties of Man and of Citizen, adopted in France (part of the modern Constitution of France), also set the principle of power division in the following wording: "Any society has no constitution if the use of rights is not ensured and the separation of powers is not carried out" (Original Declaration of the Rights of Man and of the Citizen (1789-1791)).

In our opinion, the design of power separation, based on the priority of the one power branch, does not fully correspond to the meaning of the whole concept formulated by the French philosopher of the Enlightenment epoch Sh.L. Montesquieu: "the struggle against absolutism and the usurpation of power in the hands of one", which, taking into account modern time, may sound like "the struggle against usurpation and the concentration of power in the hands of one person (a state body)".

It seems that if a parliament is the only supreme power, citizens will be deprived actually of the opportunity to express an opposite opinion until the next election, that in another situation (if all branches of power are equal on the basis of checks and balances system) they could make it through another power branch using the address to its representatives. From our point of view, it is preferable when the principle of power separation is based on the mechanism of checks and balances, ensuring their equal interaction and balancing on the basis of law.

The third idea is the idea of State activity restriction by law, realized in the Anglo-Saxon concept of the "rule of law" and the continental concept of a "rule of law state". A law is seen as a kind of "cure" against the abuse of power by a state and officials.

The fourth stage of state activity restriction development is the restriction of state activity by human rights. This theory, in general, is derived from the previous one and is based on the hypothesis that the rule of law is not an absolute value like any phenomenon.

In the opinion of its representatives the rule of law protects a citizen as a restriction of state power, but at the same time gives him into the power of soulless forms that have replaced tyranny, deprived of the possibility to take into account the human factor (suffering, helplessness, etc.): "The rule of law creates formal equality - an 
important dignity, but it contributes to the inequality by the creation of the consciousness that separates right from politics, goals from means, processes from the results radically" (Horwitz, 1986).

In relation to the mentioned above, the thesis is formulated that human rights as a universal, person-centered and the liberal idea determine the meaning and the content of the entire system of public authorities. The axiom is that power is derived from human rights and freedoms.

The reflection of this concept is Amartya Sen's opinion, the Nobel Prize laureate of 1998 "For contribution to the economic theory of welfare": "Economic science makes too much emphasis on the evaluation of state activities in the light of its expected consequences, thereby weakening the intellectual justification of the fact that fundamental individual freedoms should serve as the criteria to determine a permissible and a desirable scale of this activity" (Sen, 1999).

Recently convergence-based approaches to state power limitation emerged. They are developed by the proponents of the discursive theory of law, which was developed within the framework of the communicative theory of society written by J. Habermas, based on the interconnection (interdependence) of human rights, the idea of democracy and the idea of people's sovereignty (Habermas, 1996).

According to this concept, legitimacy is not limited to a legal design or the ability of the authorities to use the resources of violence effectively are the laws that embody the basic principles of law (social harmony, social compromise, social justice) are legitimate ones.

Thus, the idea of state power limitation by human rights fits best in the Western concept of human rights, from the perspective of which human rights are the requirement for a state to commit or refrain from certain actions; it is the means of state body abuse prevention. Human rights are the means of struggle with power abuses, because among all of the above mentioned "internal" criteria of state power limitation, they are the only ones which act as a necessary "external" factor for its activity control, a kind of individual power and the will of civil society manifestation.

The opponents of this theory argue that the recognition of human rights as the primary ones in relation to management effectiveness can cause the powerlessness of a state power, which, in its turn, threatens security, freedom and can become a determining factor for tyrannical establishment. Continuing this idea, you can unreasonably oppose state power and freedom. However, the restriction of human freedom by state power acts as a necessary condition for its provision and protection at the same time. Thus, in reality, legal freedom is confronted only by state power, not limited by law.

\section{Conclusions}

The main ideas of the above-mentioned concepts in an actualized form are reflected by the formal and legal aspect of a rule of law state essence - the principle of the most consistent linkage of a state power through the use of the law. It is the law (in subjective and objective meaning) which acts as an official civilized and the most effective regulator of social relations, the most important social, cultural and moral value, the measure of an individual's freedom and responsibility must balance out the initially unequal positions of a state (the bearer of power) and an individual (the bearer of freedom only) to the extent necessary, since everyone is equal before the law, including a state.

\section{References}

Baumgardt, D. (1952). Bentham and the Ethics of Today. Princeton University Press.

Dahl, R. A. (1998). On Democracy. Yale university press. New Haven and London.

Dinwiddy, J. (1989). Bentham. Oxford University Press.

Duguit, L. (1917). The Law and the State. Harvard Law. Review Nov., 31(1), 1-185. https://doi.org/10.2307/1327671

Friedrich, C., \& Brzezinski, Z. (1966). Totalitarian Dictatorship and Authority. Cambridge.

Habermas, J. (1996). Between Facts and Norms. Contributions to a Discourse Theory of Law and Democracy. Cambridge.

Harrison, R. (1993). Democracy. New York: Routledge.

Hart, H. L. A. (1994). The Concept of Law. Oxford: Clarendon Press.

Hauriou, M. (1929). Precis de Droit Constitutionnel. Paris: Librairie du Recueil Sirey.

Hayek, F. A. (1973). Law, Legislation and Liberty. Chicago. 
Hegel, G. (2008). Outlines of the Philosophy of Right. Oxford University Press.

Hobbes, T. (2010). Leviathan, Parts I and II. Revised Edition. Broadview Press.

Horwitz, M. (1986). Book review (of E.P. Thompson. Whigs and Hunters). Yale Law Journal.

Humboldt, W. (1969). The limits of state action. Cambridge University Press. https://doi.org/10.1017/CBO9781316036372

Hume, L. (2004). J. Bentham and Bureaucracy. Cambridge University Press, Cambridge Studies in the History and Theory of Politics.

Ishay, M. (2008). The History of Human Rights: From Ancient Times to the Globalization Era. University of California Press.

Jhering, R. (1915). The Struggle for Law. Chicago: Callaghan and Company.

Kant, I. (2010). Groundwork of the Metaphysics of Morals: A German-English Edition. Cambridge University Press.

Lijphart, A. (1977). Democracy in plural societies: a comparative exploration. New Haven and London. Yale University press.

Lindberg, D. (1980). Science in the middle Ages. University of Chicago Press, pp. 97-106.

Locke, J., \& Laslett, P. (1988). Locke: Two Treatises of Government. Student Cambridge Texts in the History of Political Thought. Cambridge University Press. https://doi.org/10.1017/CBO9780511810268

Marias, J. (2012). History of Philosophy. Courier Corporation.

Montesquieu, C., \& Richter, M. (1970). The Politcal Theory of Montesquieu. CUP Archive.

Neff, S. (2012). Hugo Grotius. Cambridge University Press.

Original Declaration of the Rights of Man and of the Citizen (1789-1791). Date Views 25.02.2017. $\mathrm{http} / / / \mathrm{www}$.unesco.org/new/en/communication-and-information/flagship-project-activities/memory-of-theworld/register/full-list-of-registered-heritage/registered-heritage-page-6/original-declaration-of-the-rights-of -man-and-of-the-citizen-1789-1791

Rosen, F. (1990). Thinking About Liberty. University College London.

Schmitt, C. (2008). The Concept of the Political. Expanded University of Chicago Press.

Sen, A. (1999). Development as Freedom. Oxford University Press.

Struan, J. (1991). Science and British Liberalism: Locke, Bentham, Mill, and Popper. Aldershot: Avebury.

United States Constitution. Date Views 25.02.2017. http://www. archives. gov/exhibits/charters/constitution.html

Wraight, C. (2008). Rousseau's 'The Social Contract'. A Reader's Guide A\&C Black.

Zhang, B. (1982). From dictatorship to democracy. Coping with the legacies of authoritarianism and totalitarizm. Westwood.

Zuckerman, A. (1975). Political Cleavage: A Conceptual and Theoretical Analysis. British Journal of Political Science, (2). https://doi.org/10.1017/S0007123400008140

\section{Copyrights}

Copyright for this article is retained by the author(s), with first publication rights granted to the journal.

This is an open-access article distributed under the terms and conditions of the Creative Commons Attribution license (http://creativecommons.org/licenses/by/4.0/). 